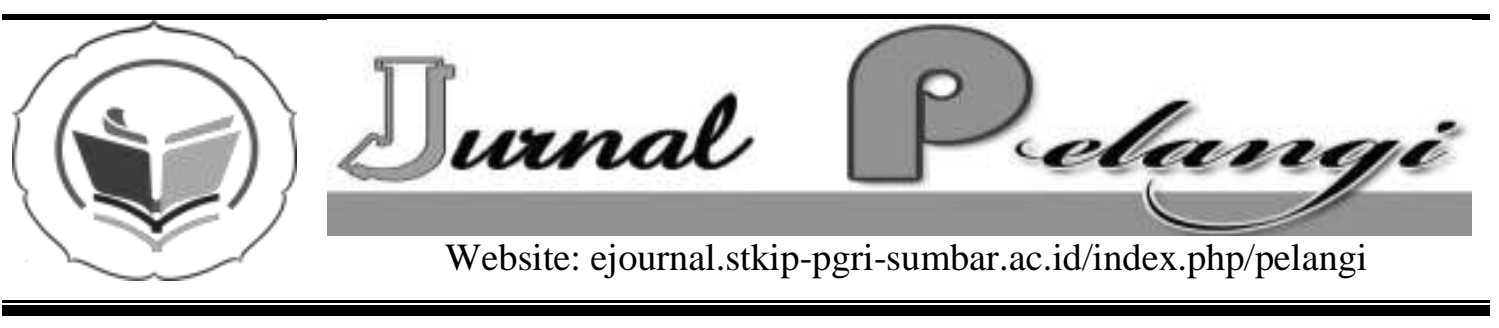

\title{
CIROLANA SP SALAH SATU ENDOPARASIT DI DANAU SINGKARAK SUMATERA BARAT
}

Dra. Renny Risdawati, M. Si

\begin{tabular}{ll}
\hline INFO & \multicolumn{1}{c}{ Abstract } \\
ARTIKEL &
\end{tabular}

Keywords:

Cirolana sp, endo parasit, Hampala sp

\section{PENDAHULUAN}

Danau Singkarak adalah salah satu danau tektonik yang terdapat di Sumatera Barat dengan luas 112,20 km. Danau ini terdapat terdapat di dua daerah tingat dua yaitu KabupatenSolok dan Kabupaten Tanah Datar. Dengan luas yang melebihi luas danau Maninjau ternyata air danau Singkarak hanya dimanfaaatkan untuk PLTA, sementara itu potensi perairan tidak dimanfaatkan untuk usaha budidaya perikanan seperti halnya perairan danau Maninjau yang dimanfaatkan untuk budidaya ikan nila dengan mengunakan jala apung ataupun keramba. Pembudidayaan ikan nila dengan menggunakan jala apung telah menjadikan danau Maninjau menjadi pusat perikanan ikan nila di Sumatera Barat yang telah mendukung pengembangan perekonomian asyarakat di sekitar danau Maninjau. Pada tahun 1997 telah pernah dilakukan budidaya ikan dengan menggunakan jala apung ternyata ikan yang dikerambakan tidak berkembang dengan baik malahan mati. Jenis ikan yang telah dikerambakan diantaranya adalah ikan Nila, ikan Mas, ikan Mujair. Dari ikan yang dikerambakan tersebut ternyata serangan tercepat terjadi pada ikan Mas dimana dari segi gerakannya ikan Mas adalah ikan yang gerakannya termasuk lambat 
(Salsabila, 1997). Pada tubuh luar ikan tersebut tidak ditemui tanda-tanda adanya serangan parasit. Akibatnya masyarakat enggan untuk melakukan budidaya lagi karena selalu merugi. Oleh karena itu diduga adanya serangan endoparasit. Dari segi ekonomi dapat juga dihitung potensi kerugian apabila potensi yang ada tidak dimanfaatkan. Untuk itu mengetahui apa yang menyebabkan kematian ikan telah dilakukan penelitian dengan mengiventarisasi endoparasit pada ikan asli danau Singkarak yaitu ikan Sasau (Hampala ).

\section{METODE PENELITIAN}

Penelitian ini telah dilakukan pada bulan Juli 2008. Metode yang digunakan adalah metode survey dan koleksi langsung dilapangan. Pengambilan sample dilakukan di restoran-restoran yang berada disekitar danau Singkarak yang menampung ikan Sasau yang ditangkap oleh nelayan. Hal ini dilakukan karena pada penelitian ini hanya mengambil sample untuk di identifikasi belum dihitung komposisinya Dari ikan sasau yang diambil adalah insang dan isi perut yang kemudian dimasukan ke dalam botol yang telah berisi formalin $10 \%$. Selanjutnya dilakukan identifikasi endoparasitnya di Laboratorium Biologi Universitas Bung Hatta Padang.

\section{HASIL PENELITIAN}

Dari hasil identifikasi di laboratorium didapatkan 2 jenis endoparasit makro pada ikan Sasau (Hampala ) yaitu Cirolana sp. yang ditemukan pada insang dan Argulus sp. yang ditemukan pada lambung .Menurut Edmonson (1966) Cirolana sp dapat diklasifikasikan ke dalam phylum Arthropoda, kelas Crustaceae, ordo Isopoda, family Cirolanidea, genus Cirolona, spesies Cirolana sp. Sedangkan Argulus diklasifikasikan ke dalam Phylum Arthropoda, kelas Crustaceae, ordo Copepoda, family Argulidae, genus Argulus dan spesies Argulus sp.

Ciri-ciri Cirolana spadalah badan memiliki tiga bagian yaitu kepala (cephalon), mempunyai dua pasang antene dan stu mulut penghisap. Bagian kedua praeon yaitu bagian antara kepala dan dada, terdiri dari tujuh segmen dengan tiga pasang kaki. Bagian dorsal yaitu tubuh bagian punggung atau atas, segmen ini memiliki kembangan seperti sayap disebut epimere (sayap).

Bagian ketiga adalah pleon yaitu bagian posterior tubuh adalah bagian belakang tubuh, terdiri dari enam segman, pada nkaki kelima terdapat anggota renang biramus yaitu pleopod (kaki renang), segmen ke enam pleotelson yaitu gabungan beberapa segmen abdominal dengan telson/ekor, berbentuk plat datar diapit oleh uropoda (kaki ekor), tubuh bermwarna coklat kekuning-kuningan (Usman, 2007).

Banyak jenis parasit yang dapat menyerang ikan asli yang terdapat di danau Singkarak, tetapi yang ditemukan dalam penelitian ini hanya 2 jenis. Hal ini di duga karena adanya pengaruh $\mathrm{pH}$ air danau Singkarak berkisar 7,00 - 8,50. Frengki (1996) menemukan 4 jenis parasit di danau Maninjau yaitu Dactylogyrus sp, Cyrodactylus sp, 
Ichthyopthirius $\mathrm{sp}$ dan Trichodina $\mathrm{sp}$ dengan $\mathrm{pH}$ air danau $6-7$.

Adanya serangan parasit pada ikan sasau (Hampala )yang merupakan ikan asli danau Singkarak diduga juga dapat menyerang ikan yang budidayakan di danau Singkarak. Pembudidayaan yang dilakukan pada tahun 1997 ternyata masih ditemukan sekarang ini.

Dari dua parasit yang ditemukan yang menyebabkan kematian pada ikan hanyalah Cirolana sp karena menyerangkan insang dimana terjadi penghisapan darah melalui gigitan. Luka bekas gigitan gamih memudahkan infeksi oleh mikroba. Ikan yang terinfeksi akan kehilangan nafsu makan, akibatnya bobot badan ikan dan daya tahan tubuh melemah, sehingga walaupun masih bertahan hidup secar ekonomis tidak menguntungkan lagi.

Parasit gamih diketahui hidup terbatas di danau Singkarak tetapi dapat juga terjadi penyebaran melalui aliran air. Cirolana sp merupakan pasit fakultatif yaitu dapat bersifat parasit pada inang yang cocok dan apabila tidak menemukan inang yang cocok dapat hidup sebagai saprofit. Agar potensi danau Singkarak dapat dikembangkan secara optimal maka perlu diperlukan usaha yang lebih hati-hati untuk memberantas gamih ini. Namun usaha yang dilakukan harus hati-hati karena parasit ini berada pada habitat alaminya. Untuk itu perlu dicarikan predator alaminya.

\section{PENUTUP}

Dari penelitian yang telah dilakukan maka dapat disimpulkan bahwa:
1.

Telah

diketahui jenis endoparasit yang berbahaya yang dapat menyerang ikan asli danau Singkarak yaitu Sasau (Hampala) dan ikan yang pernah dibudidayakan disana.

2.

Perlu

dilakukan penelitian tentang musuh alamiah (predator) untuk mengatasi gamih tersebut.

3.

ukan analisis kerugian secara ekonomi potensi danau

Singkarak yang untuk pengembangan usaha perikanan yang terabaikan.

4.

ukan analisis kerugian potensi lapangan kerja yang dapat dikembangkan apabila usaha perikanan dapat dikembangkan di danau Singkarak.

\section{DAFTAR PUSTAKA}

Anggraini,N 1996. Analisa Lambun Ikan Sasau (Hampala) yang terdapat di Danau Singkarak. Skripsi Fakultas Perikanan Universitas Bung Hatta Padang

Brotowidjoyo,M.D.1987 Parasit dan Parasitisme.Jakarta: Melton Putra

Risdawati,R 1997. Kepadatan Popolasi Ikan Bilih

(Mystacoleocus padangensis Blkr.) Serta Hubungannya denga Kepadatan Predator (Hampala ) di Danau Singkarak. Tesis Pasca Sarjana UNAND Padang.

Saanin.H.1984. Taksonomi dan Kunci Identifikasi Ikan. Bandung: Bina Cipta 
Salsabila, A. 1987 Sumberdaya Ikan

Danau Singkarak, Proceding

Seminar IV Windu FMIPA

UNAND Padang

Usman, R.2007. Parasit dan Penytakit

Ikan .Fakultas Perikanan dan Ilmu

Kelautan Unieversitas Bung

Hatta.Padang 